\section{The Ballad of the Moon and the Stag}

\section{Ljubomir Trifonĉovski Bulgaria}

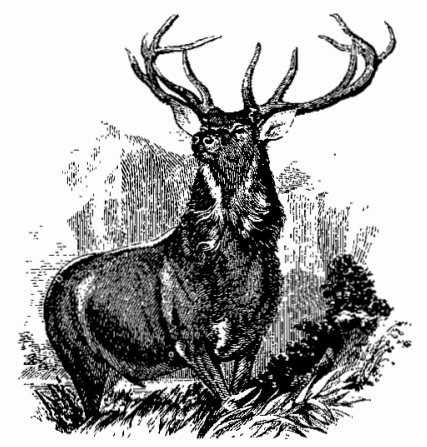

In homage to those whom I loved beyond all and who are no longer with me

Cast:

Chorus

Moon

Stag

\section{Prologue}

Chorus So black this night, only the moon does shine. The night is black indeed and one sees nothing but the moon, the moon.

Moon Midnight has passed. They should have come. Yes, coming...

Chorus But the stag comes alone.

Stag I thirst, but cannot halt.

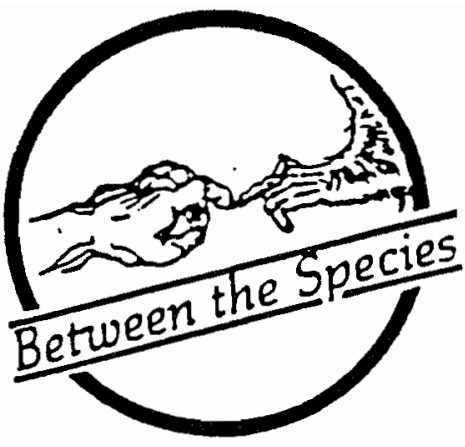

Moon Stop! Do not run.

Chorus The hunt draws near.

Stag Yes, the hunt draws near!

Moon Stop! Drink some water! And then run on.

Chorus The hunt draws near.

Stag Listen-they come! Pursuing me...

Moon And her?

Stag She...

Moon Why are you alone?

Chorus The hunt draws near. The hunt draws near.

Stag The hunt draws near!

Moon I will hide youthey will not find you. But tell-

I feel there is something to tell.

Stag Yes, something happened.

Moon Speak, do not stay silent! With bated breath I listen.

Chorus With bated breath I listen. With bated breath I listen. 
Act

Stag Once my antlers

- they were smaller then-

entangled

in branches.

I struggled.

In vain.

I called

Help! Help!

In vain.

Only the echo replied.

One hour, two went by.

Only the echo replied.

Then someone came

-it was she.

Moon So you became friends.

And then?

Stag Every night, every day

I with her.

From morning until morning she with me.

Moon You came at dusk

to the river

-I saw it all-

Drank water,

then, under the stars,

you lay down so sweetly,

she with you...

Stag Yes, she with me,

I with her.

Moon Thus - one with the otheruntil morning,

when I departed.

Chorus Until morning, when it departed.

Until morning.

Stag By day

we searched

fresh grass.

We rested

in the shade,

and played: she ran away-

I found her,

I ran-

she followed.

Until today, when...

Chorus The hunt draws near.

Stag The hunt...

Moon They will not find you this night.

Stag But in the morning they found...

Moon In the morning?

Stag I sensed

someone watching.

Among the branches

of the trees

a pair of eyes

spied on us.

We stood up and set off.

Then the call of the horn

reached us.

They were many

with guns.

Hounds bayed.

We ran

-they pursued;

I do not remember

for how long.

But a gun blasted out

and she fell.

I stopped.

Her tear-filled eyes

searched

the clouds above...

She had been wounded

in the heart.

I licked

her blood

-hopelessly.

After a minute-she died.

And again the calls!

Chorus The hunt draws near! 
Stag The hunt!

It was the hunters calling.

Moon And you ran away.

Stag I ran away.

The hunters followed.

The hounds bayed.

Throughout the day,

until evening,

and in the evening

they lost me,

but searched, still search

and will keep on searching me.

Chorus Throughout the day, until the evening, throughout the evening, throughout the day, throughout the night.

\section{Epilogue}

Moon You chose this way

- to run far away.

Will the way lead you

to safety at last?

Stag They wished to kill.

Moon You chose this way

- to run far away

- to leave your love,

your lady love.

Stag They wished to kill me too!

Did it have to be thus?

Must it be thus?

Chorus I do not know.

Stag Maybe it is more logical

to die...

So many words unsaid.

Chorus The hunt draws near.

Stag I will go.
Moon Whither?

Stag To die.

So many words unsaid

will perhaps be spoken at the end...

Moon Do you not fear?

Stag It does not matter.

Moon Must it be thus? Will it have to be thus?

Chorus I do not know.

Stag I go.

Chorus And he went.

Moon The time has come for me to go too.

Chorus Morning comes.

The moon departs.

Sunrise.

A lightening of the horizon.

The hunt draws near.

The hounds are baying.

The horns are calling.

It is morning.

Translated by Krys Ungar from the original which was written in Esperanto, the international language. 